\title{
Aecidium cinnamomi (Uredinales) has an endocyclic life cycle on Cinnamomum spp. (Lauraceae) in Indonesia
}

\author{
Dono Wahyuno • Makoto Kakishima
}

Received: 10 March 2014 / Accepted: 23 November 2014 / Published online: 12 December 2014

(C) Australasian Plant Pathology Society Inc. 2015

\begin{abstract}
A rust fungus of cinnamon trees is found throughout the year in Indonesia and seriously damages the trees, especially seedlings in nurseries. The causal rust fungus attacks leaves, petioles, shoots and young fruits. Morphological observations and inoculation experiments confirmed Aecidium cinnamomi is an endocyclic rust fungus.
\end{abstract}

Keywords Cinnamon $\cdot$ Plant pathogenic fungus $\cdot$ Spice

Cinnamomum spp. (Lauraceae) are mainly distributed in forests of Asia and Australia (Dao et al. 1999). Cinnamomum burmannii, C. cassia, C. loureirii and C. verum (syn. C. zeylanicum) are widely cultivated in South East Asia (Dao et al. 1999) because they are drought tolerant and offer shade. These trees are also economically important as sources of the spice cinnamon, which is produced from the inner bark. In Indonesia, C. burmannii is the dominant species commonly found as wild or cultivated trees in areas of 500 to $1,500 \mathrm{~m}$ above sea level.

A rust fungus of Cinnamomum spp. has been observed in the Sukabumi District, West Java Province, Indonesia since 2009. This rust fungus caused leaf malformation, necrotic spots on leaves and premature leaf defoliation

D. Wahyuno $(\bowtie)$

Indonesian Spice and Medicinal Crops Research Institute, IAARD, Tentara Pelajar No. 3, Bogor 16111, Indonesia

e-mail: dwahyuno@yahoo.ca

\section{Kakishima}

Engineering Research Center of Chinese Ministry of Education for Edible and Medicinal Fungi, Jilin Agricultural University,

Changchun, Jilin Province 130118, China

M. Kakishima

University of Tsukuba, Ibaraki 305-8572, Japan
(Fig. 1a). The rust was also observed on leaf petioles, young shoots and young fruits (Fig. 1b, c, and d). Serious damage occured to nursery seedlings and to adult trees.

Aecidium cinnamomi was first described on Cinnamomum sp. over 100 years ago in Indonesia (Raciborski 1900), where it is relatively common (Boedijn 1960; Semangun 1992; Kobayashi 2001). Aecidium cinnamomi was recently considered a taxonomic synonym of Monosporidium machili (synonyms Endophyllum machili, Aecidium machili), which causes rust on Machilus philippinensis (Lauraceae) in the Philipines (Hiratsuka et al. 1992; Sato et al. 2010). The synonymy of $A$. cinnamomi and M. machili was based on spore germination patterns and position of the spermogonia in specimens collected in Japan and the Philippines. However, Buriticá (1991) reported Endophyllum machili as the causal agent of the rust fungus of Machilus phillippinensis (Lauraceae) found in the Philippines, and treated Aecidium machili and Aecidium nakanishiki as its synonyms. Thus, further observations of specimens collected from other areas are required to confirm the taxonomic status of the rust fungus of Cinnamomum.

In this paper, we present the results of morphological studies and inoculation experiments to clarify the life cycle of $A$. cinnamomi in Indonesia. There are no previously reported morphological observations nor inoculation experiments with A. cinnamomi.

The specimens studied were preserved in the Herbarium HBI-Bal (Table 1). For light microscopy, spores and free hand sections of spermogonia and sori of infected leaves, were placed on glass slides and mounted in a drop of lactic acid solution. The types of fungal structure were determined based on the ontogenic systems proposed by Cummins and Hiratsuka (1983; 2003).

The spore surface structures were observed under a scanning electron microscope (SEM) (JEOL JSM 5310 LV) 

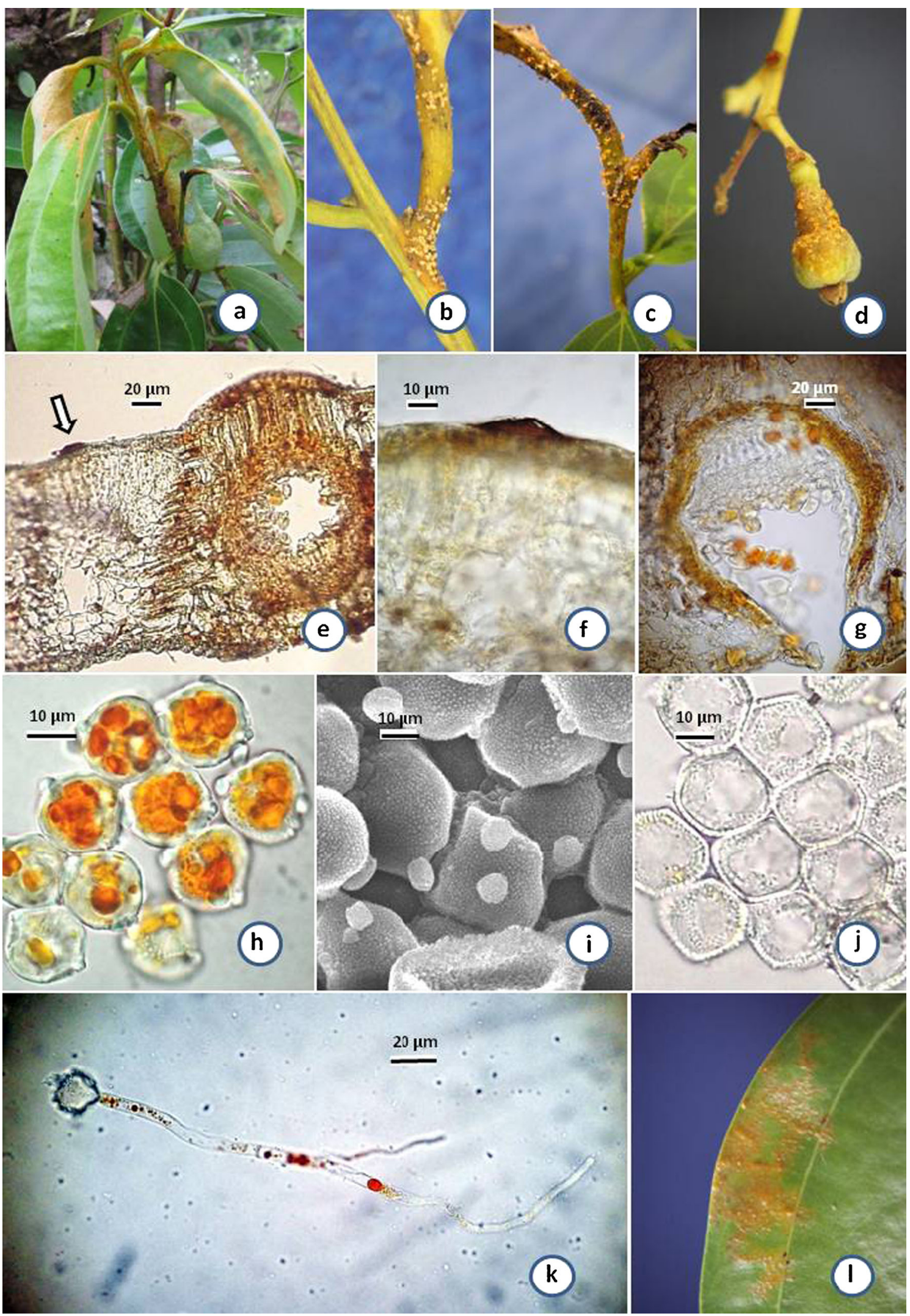

Fig. 1 Aecidium cinnamomi on Cinnamomum. (a) Symptoms, (b) Sori on leaf petiole, (c) Sori on young shoot, (d) Sori on young fruit, (e) Spermogonium $(\rightarrow$ ) on adaxial, (f) Spermogonium, (g) Sori (HBI-Bal 529), (h) Teliospores (i) Teliospores surface structure under SEM observation (HBI-Bal 529), (j) Peridial cell walls (HBI-Bal 529), (k) Germinating teliospore (HBI-Bal 529), and (l) Telial on adaxial after artificial inoculation 
Table 1 Specimens of Aecidium cinnamomi on Cinnamomum spp. collected in West Java, Indonesia

HBI-Bal (Herbarium of Balittro, Indonesian Agency for Agricultural Research and Development, Indonesia)

\begin{tabular}{llll}
\hline Specimen No. & Host & Locality & Date \\
\hline HBI-Bal 60 & C. zeylanicum & Manoko, Lembang & Jul 2, 1990 \\
HBI-Bal 175 & C. zeylanicum & Manoko, Lembang & Mar 24, 1992 \\
HBI-Bal 488 & C. burmannii & Cicurug, Sukabumi & Dec. 2009 \\
HBI-Bal 527 & C. burmannii & Cicurug, Sukabumi & Oct 15, 2010 \\
HBI-Bal 528 & C. burmannii & Cicurug, Sukabumi & May 22, 2012 \\
HBI-Bal 529 & C. burmannii & Cicurug, Sukabumi & Feb 7, 2013 \\
HBI-Bal 530 & Cinnamomum sp. & Pakuwon, Sukabumi & Sep 19, 2013 \\
\hline
\end{tabular}

operating at $20 \mathrm{kV}$. Spores and leaf pieces were attached to specimen holders and coated with gold using an E IB-2 Ion Coater.

Spores on C. burmannii collected from Sukabumi, West Java Province (HBI-Bal 529) were used for germination and inoculation experiments. The germination test was performed by placing the spores in drops of distillate water on glass slides, and then incubated for $24 \mathrm{~h}$ in dark room at $22-25^{\circ}$ C. The germinating spores were mounted in lactic acid solution, covered by cover glass and observed with a compound light microscope.

Artificial inoculation was followed the method of Morin et al. (1993). Naturally infected leaves collected from Sukabumi, West Java Province were used as the inocula. These leaves were placed in nets above the seedlings of C. burmannii in a dark humid chamber (80-90\% relative humidity; 22-25 ${ }^{\circ} \mathrm{C}$ ) for $48 \mathrm{~h}$ to release basidiospores. The inoculated seedlings were transferred to a glasshouse at 24 $28^{\circ} \mathrm{C}$ for further observation.

The spermogonia of $A$. cinnamomi subcuticular, adaxial, flask-shaped, 30.0-32.5 $\mu \mathrm{m}$ wide, and light to dark brown in colour (Fig. 1e and f). This type of spermogonium is defined as type seven (Cummins and Hiratsuka 1983, 2003). The sori have aecia-like structures with peridia, and occur predominantly on the abaxial (Fig. 1g). No other soral structure was observed in the specimens. Spores were 20.0-27.5 $\times 18.8-$ $22.5 \mu \mathrm{m}$ in size, one-celled and catenulate. The spore cell walls were 1.0-2.5 $\mu \mathrm{m}$ thick, and uniform (Fig. 1h). The spore surface structure was verrucose with refractive granules (Fig. $1 \mathrm{~h}$ and i). The peridial cell walls were hyaline, verrucose, hexagonal to irregular, and 25.0-30.0 $\times 22.5-27.5 \mu \mathrm{m}$ in size (Fig. 1j).

The spores formed basidium-like structures after germination. These structures were considered as four-celled basidia (Fig. 1k). The basidiospores produced from basidia were hyaline and globose.

Artificial inoculations revealed similar symptoms, and sori were formed on inoculated leaves. One to two weeks after inoculations, blister-like structures developed on the leaf surfaces and three to four weeks after inoculation orange sori were observed (Fig. 11).
Our results show that $A$. cinnamomi only produces telia and has an endocyclic life cycle. The spores produced in aecia functioned as teliospores that formed basidiospores. Hiratsuka et al. (1992) reported an endocylic rust fungus, Monosporidium machili on C. japonicum, Machilus japonica and Machilus khunbergii and treated A. cinnamomi as its synonym. In Japan, M. machilii was also reported on leaves of $C$. pseudopedunculatum, M. boninensis, and M. kobu (Sato et al. 2010). The morphological characteristics of the spore surface structure ornamentation, type of the spermogonia and life cycle type of the rust fungus on Cinnamomum spp. collected in Indonesia are similar to those of $M$. machili by Sato et al. (2010). However, Cummins and Hiratsuka (2003) treated Monosporidium as synonym of Endophyllum, and they also considered that Endophyllum is composed of microcyclic species that morphologically resembles Aecidium. Aecidium cinnamomi is the earliest name for the rust fungus reported on Cinnamomum (Raciborski 1900).

Until now, A. cinnamomi was reported only on C. burmanni and $C$. zeylanicum in Indonesia. In Indonesia, this rust fungus is found at altitude $500 \mathrm{~m}$ above sea level where Cinnamomum species are commonly distributed. However, the only control method to reduce its severity and spread is pruning of infected leaves and stems.

Acknowledgments Thanks to Ms. Tika and Ms. Yuni of Indonesian Institute of Sciences, Cibinong for sample preparation and SEM pictures.

\section{References}

Boedijn KB (1960) The Uredinales of Indonesia. Nova Hedwigia I:463495

Buriticá P (1991) Familias del Orden Uredinales con ciclo de vida completamente reducido. Rev Acd Colomb Cienc 18(69):131-148

Cummins GB, Hiratsuka Y (1983) Illustrated genera of rust fungi. APS Press, St Paul, p 152

Cummins GB, Hiratsuka Y (2003) Illustrated genera of rust fungi. APS Press, St Paul, p 225 
Dao NK, Hop T, Siemonsma JS (1999) Cinnamomum Schaeffer. In: de Guzman CC, Siemonsma JS (eds) Plant Resources of South-East Asia, vol 13. Backhuys Publishers, Leiden, pp 9499

Hiratsuka N, Sato S, Katsuya K, Kakishima M, Hiratsuka Y, Kaneko S, Ono Y, Sato T, Harada Y, Hiratsuka T, Nakayama K (1992) Rust flora of Japan. Tsukuba Shuppankai, Tsukuba, p 1205

Kobayashi T (2001) Diagnostic manual for tree diseases in the tropics. With some diseases of agro forestry crops. Japan Int. Forestry Promotion and Coop. Centre (JIFPRO) Soubun Printing Co. Ltd, Tokyo, p 76
Morin L, Auld BA, Brown JF (1993) Host range of Puccinia xanthii and post penetration development on Xanthium occidentale. Can J Bot 71:959-965

Raciborski M (1900) Parasitische algen und pilze java's. Bibliotheca Mycologica. Reprint 1973. J. Cramer, New York, p 39

Sato T, Uzuhashi S, Hosoya T, Hosaka K (2010) A list of fungi found in the Bonin (Ogasawara) Islands. Ogasawara Research Committee of Tokyo Metropolitan University 35:59-69

Semangun H (1992) Host index of plant diseases in Indonesia. Gadjah Mada University Press, Yogyakarta, p 351 